\title{
Polishing of Secondary Effluent by a Two-Stage Vertical-Flow Constructed Wetland
}

\author{
Chunhui Zhang*, Shuhui Tan, Juan Li, Chen Peng \\ School of Chemical and Environmental Engineering, China University of Mining and Technology (Beijing), \\ Beijing 100083, P.R. China
}

Received: 20 January 2014

Accepted: 28 March 2014

\begin{abstract}
A two-stage vertical-flow constructed wetland (VFCW) was built to advanced treatment of secondary effluent containing organic and inorganic nutrients (nitrogen and phosphorus) from a municipal sewage treatment plant in Beijing, China. The results showed that the VFCW effluent achieved $66-83 \%$ and $81-90 \%$ removal for COD and TP, respectively. Meanwhile, $\mathrm{NH}_{4}^{+}-\mathrm{N}$ and $\mathrm{TN}$ were almost completely removed during stable operation of the wetland system. The VFCW effluent concentrations of COD, TN, and TP were less than $30 \mathrm{mg} \cdot \mathrm{L}^{-1}, 1.5 \mathrm{mg} \cdot \mathrm{L}^{-1}$, and $0.3 \mathrm{mg} \cdot \mathrm{L}^{-1}$, respectively, which can meet the environmental quality standards for surface water in China. Because of the special design, the better performance of the VFCW was that it allowed the treatment of wastewater under multiple aerobic, anoxic, and anaerobic conditions sequentially in different heights of the $\mathrm{CW}$ unit. New media materials, rice husks, and steel slag were the key to the efficient removal of TN and TP. This technology could be adopted to improve the secondary effluent quality.
\end{abstract}

Keywords: vertical-flow constructed wetland (VFCW), secondary effluent, advanced treatment, nitrogen, phosphorus

\section{Introduction}

In recent years, systematic progress has been made in the field of wastewater treatment in China. In 2010 the wastewater treatment rates in the urban area and the suburbs were $95 \%$ and $53 \%$, respectively, in Beijing [1]. However, in most wastewater treatment plants the concentrations of pollutants (nitrogen, phosphorus, and other eutrophication pollutants) discharged into the water bodies still cannot meet the discharge or reuse standards in China. Hence, some efforts must be directed toward reducing the difference between the effluent concentrations and discharge limits. Membrane processes, advanced oxidation techniques, coagulation-flocculation methods, and biological aerated filter (BAF) have been applied to the advanced treatment of secondary effluent $[2,3]$. However, all of the

*e-mail: truemanjung@163.com above-advanced treatment technologies have great disadvantages of high investment and operating costs [4, 5].

Constructed wetlands (CWs) are a kind of land-based wastewater treatment system consisting of shallow ponds or trenches that contain floating or emergent rooted wetland vegetation [6]. The main advantage of $\mathrm{CW}$ is their low operating costs, the fact that they do not require any external energy source and its integration with the landscape. However, the potential of low-cost technologies like CW has only been partially explored. In general, CW is classified as surface-flow (or free water surface) and sub-surface flow. Sub-surface flow CWs are further classified as horizontal flow and vertical-flow wetlands (VFCW). Some previous studies have shown the overall effectiveness of CWs in treating municipal or industrial wastewater [7, 8]. Temperature, hydraulic residence time (HRT), vegetation type, media material, and CW type play important roles in performing $\mathrm{CW}$ treating wastewater [7]. 
Table 1. Characteristics of media materials.

\begin{tabular}{|c|c|c|c|c|}
\hline Parameter & $\begin{array}{l}\text { Height range } \\
\qquad(\mathrm{mm})\end{array}$ & $\begin{array}{l}\text { Media } \\
\text { materials }\end{array}$ & $\begin{array}{l}\text { Diameter range } \\
\qquad(\mathrm{mm})\end{array}$ & $\begin{array}{l}\text { Main elements/ } \\
\text { Description }\end{array}$ \\
\hline \multirow{3}{*}{$\begin{array}{c}\text { Down flow } \\
\text { CW unit }\end{array}$} & $0-100$ & Cobble & $20-50$ & \\
\hline & $100-350$ & Zeolite & $5-20$ & $\mathrm{Al} 8.23 \%$; Fe $1.01 \%$; Ca $2.83 \%$; Mg 0.4\% \\
\hline & $350-550$ & Gravel & $1-5$ & $\mathrm{Al} 6.83 \% ; \mathrm{Fe} 4.44 \% ; \mathrm{Mg} 0.51 \%$ \\
\hline \multirow{3}{*}{$\begin{array}{l}\text { Up flow } \\
\text { CW unit }\end{array}$} & $0-100$ & Cobble and rice husk & $\begin{array}{l}\text { Cobble: } 20-50 \\
\text { Rice husk: } 3-5\end{array}$ & Rice husk and cobble in a volume ratio of $1: 1$ \\
\hline & $100-350$ & Steel slag & $10-20$ & Si 14.5\%; Al 2.22\%; Fe 22.64\%; Ca 46.74\%; Mg 8.48\% \\
\hline & $350-550$ & Limestone & $2-10$ & $\mathrm{Al} 3.06 \% ; \mathrm{Fe} 0.86 \%$; Ca 32.06\%; Mg 2.09\% \\
\hline
\end{tabular}

BOD, COD, nitrogen, phosphorus, trace elements, and some metals can be effectively removed in CW systems [912]. Among these pollutants, the nutrients nitrogen and phosphorus are the main targets of $\mathrm{CW}$ for their difficulty to remove. The $\mathrm{N}$ removal in $\mathrm{CW}$ is based on ammonification, nitrification, and denitrification. The $\mathrm{P}$ removal in $\mathrm{CW}$ occurs by storing in the sediment and soil via the sedimentation of particulate $\mathrm{P}$, chemical precipitation, and adsorption of soluble $\mathrm{P}$, and deposition of suspended organic matter [13].

To improve the $\mathrm{N}$ removal efficiency of $\mathrm{CW}$, Tee et al. [14] applied a baffled subsurface-flow CW with many baffles inside of the horizontal subsurface flow. Their research results proved that the baffled $\mathrm{CW}$ was better than conventional unbaffled $\mathrm{CW}$ in treatment of $\mathrm{N}$ removal. Use of a steel slag filter of electric arc furnace following $\mathrm{CW}$ has been shown to significantly increase P removal [15]. In this study, we applied a two-stage VFCW containing steel slag media to remove $\mathrm{N}$ and $\mathrm{P}$ in secondary effluent from a municipal sewage treatment plant.

\section{Materials and Methods}

\section{Materials}

All chemicals used in the experiments were reagent grade or higher and were used as received without further purification. Gravel and cobbles were obtained from the Chaobaihe river bed. Zeolite and limestone were purchased from Henan Gongyi Filter Material Plant. Steel slag was obtained from Capital Iron and Steel Plant, and rice husk was collected from a local village near the Miyun Wastewater Treatment Plant. The rice husks were washed repeatedly with tap water and then dried under sunlight before use.

\section{Experimental-Scale CW Description}

Two separate $\mathrm{CW}$ units were made of plexiglass with diameter of $50 \mathrm{~cm}$ and height of $65 \mathrm{~cm}$. The two units were linked by series connection (Fig. 1). Along with the flow direction, a total of 9 sampling taps were installed, including No. 1 for influent, No. 5 and No. 9 for downstream and upstream effluent, respectively. No. 2 to No. 4 and No. 8 to No.6 sampling taps were placed at height of $10 \mathrm{~cm}, 30 \mathrm{~cm}$, and $50 \mathrm{~cm}$ below the surface media.

The porous media materials were placed in each unit at a height of $55 \mathrm{~cm}$, and the plants were planted. Six kinds of porous media materials were used in the experiments (Table 1).

The influent and effluent water were distributed through 'H shaped' perforated stainless steel pipe. The hydraulic loading rate was maintained at $0.1 \mathrm{~m}^{3} \cdot \mathrm{m}^{-2} \cdot \mathrm{d}^{-1}$. The common reed collected from Chaobaihe River was selected as the vegetation of the $\mathrm{CW}$.

\section{Sampling}

Influent CW samples were collected from the secondary effluent of the Miyun Wastewater Treatment Plant. The characteristics, discharge limit for effluent, and surface water quality standard were listed in Table 2.

As shown in Table 2, the main parameters such as COD, $\mathrm{NH}_{4}^{+}-\mathrm{N}, \mathrm{TN}$, and TP of Miyun WWTP secondary effluent could not basically meet either the discharge limit or surface water quality standards, basically in China.

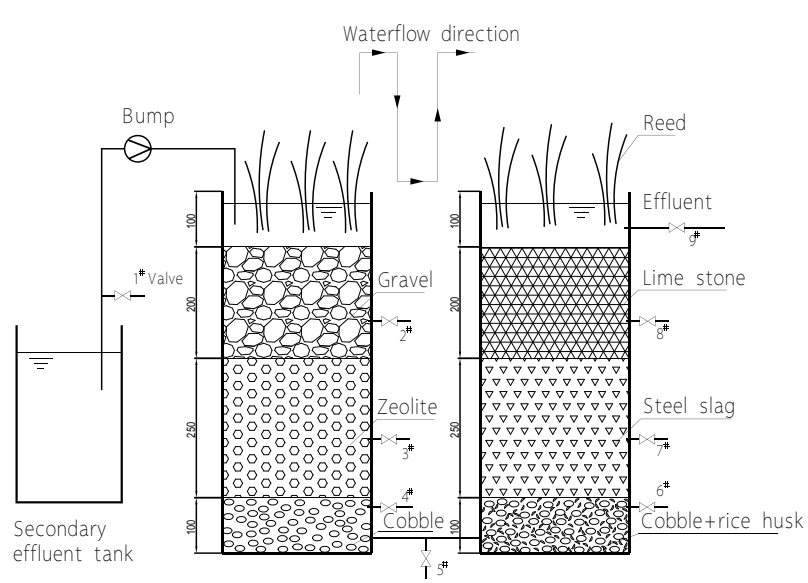

Fig. 1. The experimental scale two-stage vertical-flow constructed wetland. 
Table 2. The characteristics, discharge limit for effluent, and surface water quality standard.

\begin{tabular}{|c|c|c|c|}
\hline Parameters & $\begin{array}{c}\text { Concentration range } \\
\left(\mathrm{mg} \cdot \mathrm{L}^{-1}\right)\end{array}$ & $\begin{array}{c}\text { Discharge limit for WWTP effluent in } \\
\text { China }\left(\mathrm{mg} \cdot \mathrm{L}^{-1}\right) \\
(\mathrm{GB} 18918-2002, \mathrm{Grade} 1 \mathrm{~A})\end{array}$ & $\begin{array}{c}\text { Environmental quality standards for surface } \\
\text { water in China }\left(\mathrm{mg} \cdot \mathrm{L}^{-1}\right) \\
(\mathrm{GB} 3838-2002, \text { Class } 4)\end{array}$ \\
\hline $\mathrm{COD}$ & $33.6-82.1$ & 50 & 30 \\
\hline $\mathrm{NH}_{4}^{+} \mathrm{N}$ & $8.5-12.8$ & 5.0 & 1.5 \\
\hline $\mathrm{TN}$ & $15.6-32.0$ & 15 & 1.5 \\
\hline $\mathrm{TP}$ & $0.89-1.23$ & 0.5 & 0.3 \\
\hline
\end{tabular}

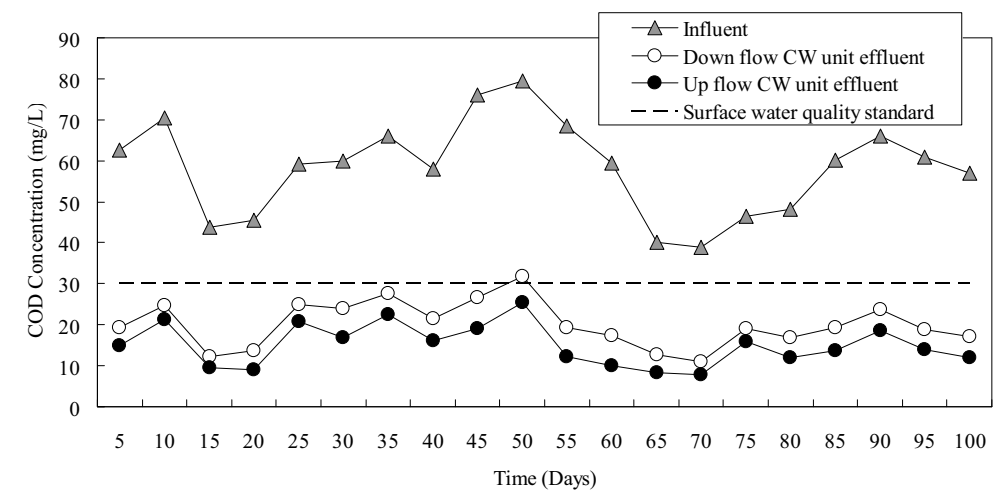

Fig. 2. Removal efficiency of COD. The vertical bars are standard deviations of the means. $n=3$.

\section{Analytical Method}

Analyses of the samples taken from the influent and effluent of $\mathrm{CW}$ units included the following parameters: $\mathrm{COD}, \mathrm{NH}_{4}^{+}-\mathrm{N}, \mathrm{NO}_{3}-\mathrm{N}, \mathrm{TN}$, and TP. All analyses were made according to standard methods of China [16].

\section{Results and Discussion}

\section{Purifying Effect on the COD}

The removal efficiency of COD was recorded from June to August 2011 after the operation of the constructed wetland as presented in Fig. 2. Under a relatively high fluctuation of influent concentration $\left(33.6 \sim 82.1 \mathrm{mg} \cdot \mathrm{L}^{-1}, \mathrm{COD}\right)$ during the period, the COD of the effluent was below 30 $\mathrm{mg} \cdot \mathrm{L}^{-1}$, which indicated that VFCW effluent met the expected environmental quality standards for surface water in China (GB 3838-2002) [17]. Wastewater in wetlands was purified by complex processes which included interaction among aquatic plants, micro-organisms, media filtration, and adsorption [18]. The COD removal efficiency of twostage VFCW was $66-83 \%$, while the COD removal efficiency of downflow $\mathrm{CW}$ unit was $58-72 \%$, which plays a major role in COD removal. Filtered by $0.45 \mu \mathrm{m}$ filter paper, COD was analyzed both in untreated wastewater and filtered wastewater. COD of filtered wastewater accounted for $36-48 \%$ of untreated wastewater COD, which indicated that particulate solid materials accounted for $52-64 \%$ of the influent COD. Obviously, it concluded that COD pollutants of particulate solid materials were mainly removed by

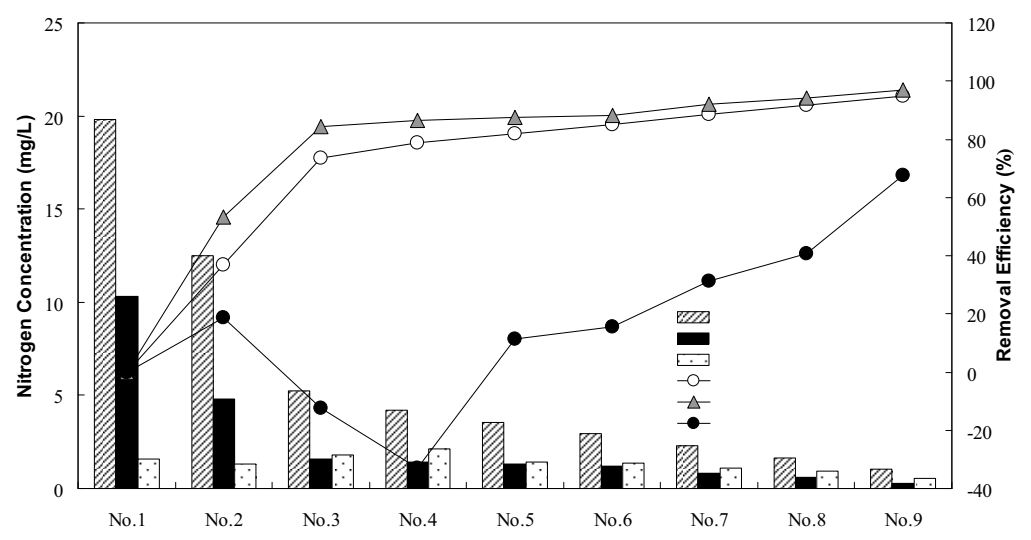

Fig. 3. Removal efficiency of Nitrogen. The vertical bars are standard deviations of the means. $n=3$. 


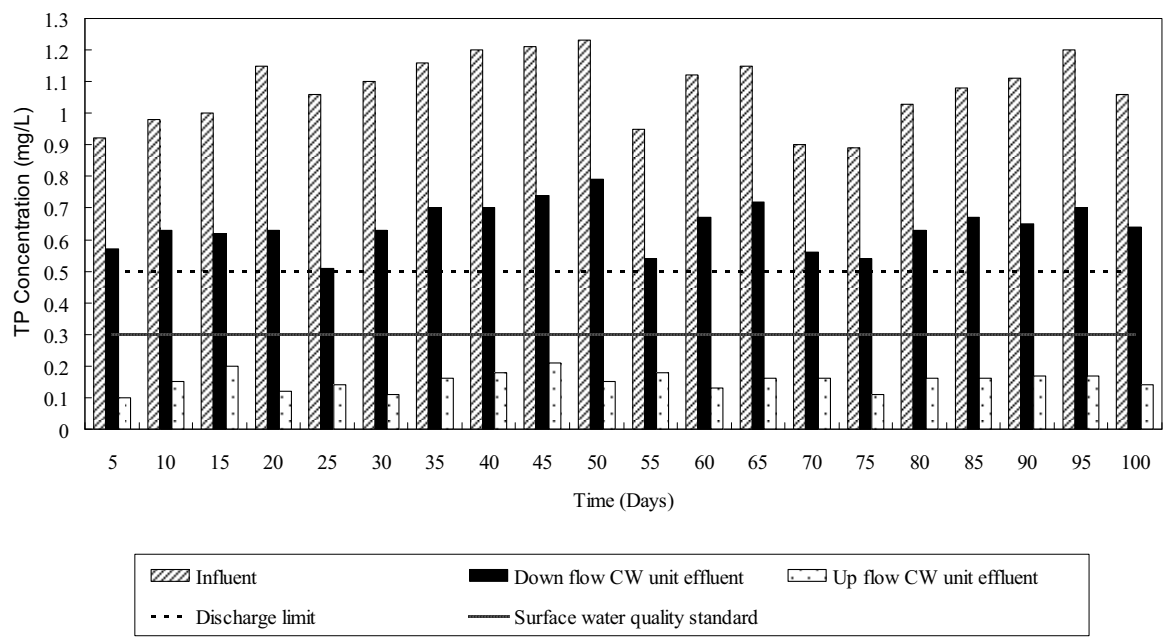

Fig. 4. Removal efficiency of TP. The vertical bars are standard deviations of the means. $n=3$.

media filtration and adsorption in the down flow $\mathrm{CW}$ unit and COD were further removed by microbial degradation in the up flow $\mathrm{CW}$ unit.

\section{Purifying Effect on Nitrogen}

Nitrogen has a complex biogeochemical cycle with biotic/abiotic transformations involving seven valence states ( +5 to -3$)$. The compound includes a variety of inorganic and organic nitrogen forms that are essential for all biological life [7]. Fig. 3 represents mean concentration values and removal efficiencies of $\mathrm{NH}_{4}^{+}-\mathrm{N}, \mathrm{NO}_{3}-\mathrm{N}$, and $\mathrm{TN}$ in two-stage VFCW.

$\mathrm{NH}_{4}^{+}-\mathrm{N}$ and $\mathrm{TN}$ were removed effectively after the advanced treatment of two-stage VFCW. Previous research had shown that $\mathrm{NH}_{4}^{+}-\mathrm{N}$ in VFCW achieved high removal efficiency but very limited in TN [7]. In our study, the excellent removal efficiency of TN was particularly striking in view of relatively high $\mathrm{NH}_{4}^{+}-\mathrm{N}$ concentrations contained in the influent. From No. 2 to No. 4 sampling taps, $\mathrm{NH}_{4}^{+}-\mathrm{N}$ was mainly removed in the down flow VFCW. This was mainly due to the role of media materials adsorption and interception. From No. 1 to No. 2 sampling taps, the $\mathrm{NO}_{3}-\mathrm{N}$ concentration did not increase but decreased. Then the $\mathrm{NO}_{3}-\mathrm{N}$ concentration increased until attaining the maximum value $\left(2.13 \mathrm{mg} \cdot \mathrm{L}^{-1}\right)$ at No. 4 sampling tap. After that, the $\mathrm{NO}_{3}-\mathrm{N}$ concentration began to decrease. The increased $\mathrm{NO}_{3}-\mathrm{N}$ concentration was due to nitrification of $\mathrm{NH}_{4}^{+}-\mathrm{N}$. Nitrification was a chemoautotrophic process, where nitrifying bacteria derive energy from the oxidation of ammonia or nitrite and carbon dioxide, which was used as a carbon source for the synthesis of new cells. Nitrification was a two-step process involving two groups of microorganisms. One microbial group oxidized ammonium- $\mathrm{N}$ to nitrite- $\mathrm{N}$ and nitrite- $\mathrm{N}$, and another oxidized nitrite-N to nitrate-N:

$$
\begin{aligned}
& \mathrm{NH}_{4}^{+}+1.5 \mathrm{O}_{2} \rightarrow \mathrm{NO}_{2}^{-}+2 \mathrm{H}^{+}+\mathrm{H}_{2} \mathrm{O} \\
& \mathrm{NO}_{2}^{-}+0.5 \mathrm{O}_{2} \rightarrow \mathrm{NO}_{3}^{-} \\
& \mathrm{NH}_{4}^{+}+2 \mathrm{O}_{2} \rightarrow \mathrm{NO}_{3}^{-}+2 \mathrm{H}^{+}+\mathrm{H}_{2} \mathrm{O}
\end{aligned}
$$

When $\mathrm{NO}_{3}-\mathrm{N}$ concentration decreased after No. 4 sampling tap, the denitrification began to proceed. Denitrification is most commonly defined as the process in which nitrate is converted into dinitrogen via intermediates nitrite, nitric oxide, and dinitrogen via intermediates nitrite, nitric oxide, and nitrous oxide [19, 20]. From the biochemical point of view, denitrification is a bacterial process in which nitrogen oxides (in ionic and gaseous forms) serve as terminal electron acceptors for respiratory electron transport. Electrons are carried from an electron-donating substrate (usually, but not exclusively, organic compounds) through several carrier systems to a more oxidized $\mathrm{N}$ form. The resultant free energy is converted in ATP, following phosphorylation, and is used by the denitrifying organisms to support respiration. Denitrification is illustrated by the equation as follows [21]:

$$
6\left(\mathrm{CH}_{2} \mathrm{O}\right)+4 \mathrm{NO}_{3}^{-} \rightarrow 6 \mathrm{CO}_{2}+2 \mathrm{~N}_{2}+6 \mathrm{H}_{2} \mathrm{O}
$$

The $\mathrm{NO}_{3}-\mathrm{N}$, concentration increased gradually in the down flow VFCW unit due to the nitrification of ammonia ions. So nitrification accounted for a dominant role in the down flow VFCW unit. Whereas in the up flow VFCW unit, with the reduction of oxygen content, denitrification dominated the nitrogen reaction. Then the $\mathrm{NO}_{3}-\mathrm{N}$ concentration decreased with the transition from the $\mathrm{NO}_{3}-\mathrm{N}$ to $\mathrm{N}_{2}$. In order to provide sufficient carbon source for denitrification, the rice husk was selected as media materials to accompany with the cobble in the bottom of up flow VFCW unit.

\section{Purifying Effect on the Phosphorus}

As shown in Fig. 4, the TP removal efficiency of twostage VFCW is $81-90 \%$. The TP removal efficiency of down flow CW unit is $36-48 \%$, which indicates that the up flow CW unit plays a major role for removing TP. The removal process of TP involves plant adsorption, microbial metabolism, media adsorption, and precipitation. The role of plant adsorption and microbial metabolism is small 
[22]. Therefore, media adsorption and precipitation of phosphorus is a key way for the remediation of phosphorus in the wastewater. The up flow $\mathrm{CW}$ unit is filled with steel slag ( $\mathrm{Ca} 46.74 \%, \mathrm{Al} 2.22 \%$, Fe 22.64\%) and limestone (Ca 32.06\%, $\mathrm{Al} 3.06 \%$, Fe 0.86\%) media, which are rich in calcium, aluminum, and iron ions. The reaction of calcium, aluminum, iron, and phosphate ions can form sediment, which can remove phosphorus of the wastewater.

Since the mid 1990s, CWs have been increasingly used as a low-energy 'green' technique in the treatment of wastewater [23]. Compared with the wastewater discharge or reuse standards in China, the TN and $\mathrm{P}$ are the most difficult organic pollutants to be removed. The special design of two-stage vertical flow $\mathrm{CW}$ achieved the treatment of wastewater under multiple aerobic, anoxic, and anaerobic conditions sequentially in different heights of the $\mathrm{CW}$ unit, which could promote the $\mathrm{NO}_{2}-\mathrm{N}$ and $\mathrm{NO}_{3}-\mathrm{N}$ conversion ability to $\mathrm{N}_{2}$ for the organic-rich wastewater leading to higher TN removal rates [24]. In our experiments, we applied rice husk as one of several substrate materials in $\mathrm{CW}$. In fact, the rice husk cannot only increase the $\mathrm{C}$ content but also allow the roots of vegetation to grow deeper, which promotes plant uptakes and decreases the risk of clogging of $\mathrm{CW}$ [25]. In order to achieve better $\mathrm{P}$ removal efficiency, zeolite, and steel slag are selected as substrate materials of $\mathrm{CW}$ in our experiments. Zeolite owns a highly adsorbent ability for $\mathrm{P}$ in wastewater [26]. In addition, zeolite enhances the HRT by increasing the capacity for shrinkage and swelling in the mixed substrate [27]. The steel slag filler is selected as one of the substrates in our experiments. Steel slag has been found to be rich in iron and calcium oxides, promoting $\mathrm{P}$ removal. According to the research results of Drizo et al. [15], steel slag demonstrated nearly $100 \%$ P removal efficiency as substrate of CW over a period of 180 days. Cost is another important requirement in substrate selection in CW. In our experiments, all the selected substrate materials such as gravel, zeolite, cobble, rice husk, steel slag, and limestone are cheap materials or industrial and agricultural wastes.

\section{Conclusions}

A two-stage vertical-flow constructed wetland showed a clean performance in reducing organic pollutants in the secondary effluent of WWTP. The better performance of the VFCW was because of the special design that allowed the treatment of wastewater under multiple aerobic, anoxic, and anaerobic conditions sequentially in different heights of the $\mathrm{CW}$ unit. New media materials like rice husk and steel slag were key to the efficient removal of TN and TP, respectively. The whole design of two-stage vertical-flow $\mathrm{CW}$ provided an environmentally-friendly treatment cycle. The technique could be employed to improve the secondary effluent quality.

\section{Acknowledgements}

The authors would like to thank the China Central University Special Basic Research Fund (Grant No. 2011QH01), which is supported by the Chinese Ministry of Education.

\section{References}

1. Beijing Municipal Environmental Protection Bureau Beijing Environmental Statement, Beijing, 2011.

2. RUPPERT G., BAUER R., HEISLER G. UV-O $\mathrm{O}_{3}, \mathrm{UV}-\mathrm{H}_{2} \mathrm{O}_{2}$, $\mathrm{UV}-\mathrm{TiO}_{2}$ and the photo-Fenton reaction: Comparison of advanced oxidation processor for wstewater treatment. Chemosphere. 28, 1447, 1994

3. WU S.Q., YUE Q.Y., QI Y.F., GAO B.Y., HAN S.X., YUE M. Preparation of ultra-lightweight sludge ceramics (ULSC) and application for pharmaceutical advanced wastewater treatment in a biological aerobic filter (BAF). Bioresource Technol. 102, 2296, 2011.

4. ALATON I.A., BALCIOGLU I.A., BAHNEMANN D.W. Advanced oxidation of a reactive dyebath effluent: comparison of $\mathrm{O}_{3}, \mathrm{H}_{2} \mathrm{O}_{2} / \mathrm{UV}-\mathrm{C}$ and $\mathrm{TiO}_{2} / \mathrm{UV}-\mathrm{A}$ processes. Water Res. 36, 1143, 2002.

5. LUCAS M.S., PERES J.A., PUMA G.L. Treatment of winery wastewater by ozone-based advanced oxidation processes $\left(\mathrm{O}_{3}, \mathrm{O}_{3} / \mathrm{UV}\right.$ and $\left.\mathrm{O}_{3} / \mathrm{UV} / \mathrm{H}_{2} \mathrm{O}_{2}\right)$ in a pilot-scale bubble column reactor and process economics. Sep. Purif. Technol, 72, 235, 2010.

6. GOTTSCHALL N., BOUTIN C., CROLLA A., KINSLEY C., CHAMPAGNE P. The role of plants in the removal of nutrients at a constructed wetland treating agricultural (dairy) wastewater, Ontario, Canada. Ecol. Eng. 29, 154, 2007.

7. VYMAZAL J. The use constructed wetlands with horizontal sub-surface flow for various types of wastewater. Ecol. Eng. 35, 1, 2009.

8. ZHANG H.G., CUI B.S., HONG J.M., ZHANG K.J. Synergism of natural and constructed wetlands in Beijing, China. Ecol Eng. 37, 128, 2011.

9. NERALLA S., WEAVER R.W., LESIKAR B.J., PERSYN R.A. Improvement of domestic wastewater quality by subsurface flow constructed wetlands. Bioresour. Technol. 75, 19, 2000.

10. AKRATOS C.S., TSIHRINTZIS V.A. Effect of temperature, HRT, Vegetation and porous media on removal efficiency of pilot-scale horizontal subsurface flow constructed wetlands. Water Res. 29, 173, 2008.

11. MATAMOROS V., GARCÍA J., BAYONA J.M. Organic micropollutant removal in a full-scale surface flow constructed wetland fed with secondary effluent. Water Res. 42, 653, 2008.

12. VYMAZAL J., KRÖPFELOVÁ L. Removal of organics in constructed wetlands with horizontal sub-surface flow: A review of the field experience. Sci. Total Environ. 407, 3911, 2009.

13. HUANG X.F., LING J., XU J.C., FENG Y., LI G.M. Advanced treatment of wastewater from an iron and steel enterprise by a constructed wetland/ultrafiltration/reverse osmosis process. Desalination. 269, 41, 2011.

14. TEE H.C., LIM P.E., SENG C.E., NAWI M.A.W. Newly developed baffled subsurface-flow constructed wetland for the enhancement of nitrogen removal. Bioresource Technology. 104, 235, 2010. 
15. DRIZO A., FORGET C., CHAPUIS R.P., COMEAU, Y Phosphorus removal by electric arc furnace steel slag and serpentinite. Water Res. 40, 1547, 2006.

16. XI D.L., SUN Y.S., LIU X.Y. Environmental monitoring, Beijing: Higher Education Press, China, pp. 1-116, 2004.

17. GB 3838-2002, China, Environmental quality standards for surface water, 2002.

18. LEE C.G., FLETCHER T.D., SUN G.Z. Nitrogen removal in constructed wetland systems. Eng. Life Sci. 9, 11, 2009.

19. PAUL E.A., CLARK F.E. Soil microbiology and biochemistry. $2^{\text {nd }}$ ed. San Diego, California: Academic Press, 1-52, 1996.

20. SCHMIDT I., SLIEKERS O., SCHMID M., BOCK E., FUERST J., KUENEN J.G., JETTEN M. S. M., STROUS M., New concepts of microbial treatment process for the nitrogen removal from wastewaters. FEMS Microbiol. Rev. 27, 481, 2003

21. HAUCK R.D. Atmospheric nitrogen chemistry, nitrification, denitrification, and their relationships. In: Hutzinger $\mathrm{O}$, editor. The handbook of environmental chemistry. Vol. 1 Part $\mathrm{C}$, the natural environment and biogeochemical cycles. Berlin: Springer-Verlag; 105, pp. 1-85, 1984

22. ZHANG C.H., NING KE., ZHANG W.W., GUO Y.J., CHEN J., LIANG C. Determination and removal of antibi- otics in secondary effluent using a horizontal subsurface flow constructed wetland, Environ. Sci.: Processes Impacts, 15, 709, 2013

23. WU S.B., WIESSNER A., DONG R.J., PANG C.L., KUSCHK P. Performance of two laboratory-scale horizontal wetlands under varying influent loads treating artificial sewage. Eng. Life Sci. 12, 178, 2012.

24. HU Y.S., KUMAR J.L.G., AKINTUNDE A.O., ZHAO X.H., ZHAO Y.Q. Effects of livestock wastewater variety and disinfectants on the performance of constructed wetlands in organic matters and nitrogen removal. Environ. Sci. Pollut. R. 18, 1414, 2011.

25. BIALOWIEC A., JANCZUKOWICZ W., RANDERSON P.F. Nitrogen removal from wastewater in vertical flow constructed wetlands containing LWA/gravel layers and reed vegetation. Ecol. Eng. 37, 897, 2011.

26. ALLENDE K.L., FLETCHER T.D., SUN G. The effect of substrate media on the removal of arsenic, boron and iron from an acidic wastewater in planted column reactors. Chem. Eng. J. 179, 119, 2012.

27. BRUCH I., FRITSCHE J., BÄNNINGER D., ALEWELL U., SENDELOV M., HÜRLIMANN H., HASSELBACH R., ALEWELL C. Improving the treatment efficiency of constructed wetlands with zeolite-containing filter sands. Bioresour. Technol. 102, 937, 2011. 